\title{
The Influence of Spiritual Quotient Toward Subjective Well-Being of Student of Muhammadiyah Boarding School Yogyakarta High School
}

\author{
Agus Yuliyanto, Setyabudi Indartono
}

\begin{abstract}
The purpose of this study was to determine the effect of spiritual quotient towards subjective well-being of students in Muhammadiyah Boarding School Yogyakarta High School. This research was quantitative research. The subject of this research was students of class $X$ and XI of Muhammadiyah Boarding School Yogyakarta High School as many as 227 students. The technique of data collection was using scale of spiritual quotient and scale of subjective well-being in theform of questionnaire. Data analysis was using simple linier regression analysis. The results of this study indicated that: (1) as many as 211 students $(92,95 \%)$ have high level of spiritual quotient, 16 students (7,05\%) have moderate level of spiritual quotient and there was no low level of spiritual quotient of student, (2) as many as 176 students (77,53\%) have high level of subjective well-being, 51 students $(22,47 \%)$ have moderate level of subjective well-being and there was no low level of subjective wellbeing of student, (3) Spiritual quotient has positive effect and significant toward subjective well-being of students in Muhammadiyah Boarding School Yogyakarta High School as big as $48 \%$ with significant value (Sig.) of 0,000 and t-count as big as $14,418$.
\end{abstract}

Keywords: Boarding School, Spiritual Quotient, Subjective Well-Being.

\section{INTRODUCTION}

States one of the most meaningful forms of positive emotion is happiness. According to Grimaldy et al (2017:102103)[1]. Happiness is an individual judgment of himself because of the emotions he felt especially positive emotions and the individual was satisfied with what he felt. An individual who gets a pleasant life experience will elicit positive emotions. Feelings of contentment or individual satisfaction against the emerging positive emotions deliver the individual to happiness.

In Indonesia, a series of activities and the development of measuring instruments of the level of happiness of Indonesian people are implemented by the Indonesian Statistical Agency (BPS) of the Republic of Indonesia from 2012. BPS recognizes that it is increasingly recognized that the size of happiness (happiness) is important to be examined. Diener explains the happiness with the concept of well-being subjective or subjective wellbeing. According to Diener (in Anggoro \& Widiarso 2010:176) [2]. The concept of subjective well-being (SWB) is widely used in the study of individual happiness. According to him, some psychology researchers tend to equate the term happiness with subjective well-being.

Revised Manuscript Received on August 15, 2019.

* Correspondence Author

Agus Yuliyanto*, Graduate School, Yogyakarta State University, Indonesia E-mail: agusyuliyanto.2017@student.uny.ac.id

Setyabudi Indartono, Graduate School, Yogyakarta State University, Indonesia E-mail: setyabudi_indartono@uny.ac.id

(C) The Authors. Published by Blue Eyes Intelligence Engineering and Sciences Publication (BEIESP). This is an open access article under the CC BY-NC-ND license (http://creativecommons.org/licenses/by-nc-nd/4.0/)
However, there are also those who argue that subjective prosperity is a broader and more comprehensive concept encompassing happiness itself.

Subjective prosperity is one of the studies of positive psychology. According to Diener, Lucas and Oishi Subjective prosperity is the result of the evaluation or assessment of a person cognitive and affective about their experience in life (2005:63)[3]. Diener explains that subjective prosperity focuses on an individual's evaluation of their lives, individuals who have a high subjective wellbeing to feel a pleasant emotion, feeling less emotionally Unpleasant and a little feel of pain. One who has a subjective welfare tends to feel satisfied with their lives (2000:34)[4].

\section{LITERATURE REVIEW}

\section{A. Subjective Well-Being}

Maslilah describes the factors that affect the subjective welfare of an individual i.e. internal factors sourced from inside and external from the environment. Internal factors include the ability to overcome problems and pressures, ability to conform to environment and spirituality. While external factors include family support, peer support and the support of an individual's party are located. (2017:89)[5].

The subjective welfare of teenagers who were at school level had the benefit of having the youth feel the satisfaction of his life, spared the negative Aphek and possessed a positive affective. When teenagers feel contentment and experience the positive emotion of the youth will achieve optimal development to achieve the goal of education. Teenagers who have subjective well-being tend to feel joyful, peaceful, absence of depressed feelings. Teenagers can enjoy the education process so that they can complete their academic duties well. The subjective Kesejahteraaan is also beneficial in order for the youth to avoid behavioral deviations that can harm the education process.

Meanwhile, youth who have hope or a goal, but fail in achieving the expectations or goals will likely experience a negative emotional experience. The experience of negative emotions that arise because of unhappiness experienced by adolescents occurs because youth are not able to achieve satisfaction for themselves. When teenagers do not achieve what they want, teenagers tend to be irritable and emotionally elevated. According to the characteristics of the youth who made Izzaty et al, that adolescence as an unrealistic time. Negative emotional experiences will make the youth feel less prosperous (2013:123)[6].

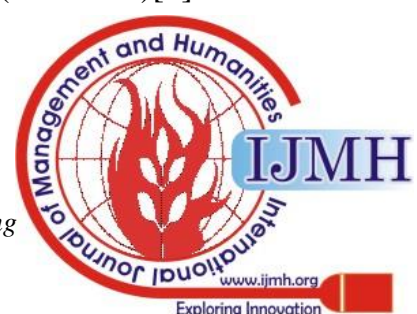


The low subjective prosperity poses an impact on unhealthy personalities and adverse behaviors. So, teenagers need to achieve positive emotions such as happiness to avoid it. According to Azizah the happiness that adolescents achieve can keep themselves away from serious problems or keep themselves away from the predicates of serious troubled youth or behavioral deviations (2013, 512-513)[7]. Based on the findings in SMA Muhammadiyah Boarding School Yogyakarta is known that some students experience issues such as students feel minder, envy with friends, feel not to have a proud achievement, financial problems and time issues. The issue triggers the emergence of negative emotions such as uncomfortable, anxious, unhappy, dissatisfied and other negative emotions

Boarding school students who interact often with other students both at school and in dormitories with different family backgrounds trigger the behavior of Membandingbandingkan themselves with other students. Students feel less fortunate than other students, feel jealous for assuming other students are more fortunate than he is. Some students feel inferior because they don't yet have a proud feat things.

Financial issues bring anxiety to students. Students need to spend money to buy daily necessities or simply to snack. Students can lack or run out of money to buy daily necessities, snacks, and other necessities because they have not gotten a shipment from a family or lack of good financial management. If insufficient finances can trigger student anxiety.

Free time is time beyond the daily activities that students live. Free time is required for students to do hobbies, breaks and things that make students happy. Students who feel the free time is lacking because school and boarding activities cause students to not be able to do what they are pleased with. Some students are also not capable of good time management so as to forget the duties and obligations because it is too soluble with other activities at leisure. This can elicit feelings of dissatisfaction and negative emotions in the form of displeased and discomfort.

Envy, minder, inferiority and dissatisfaction can bring out negative emotions so that the students ' subjective welfare levels decrease. Individual adaptation to the problems of life is the determining factor of subjective welfare whether low or high (Nayana, 2003:234)[8]. Students as learners assume the responsibility to optimize the potential that is owned so as to achieve optimal performance in the educational process. Optimizing student performance is influenced by the subjective welfare of students. The school also contributes to the achievement of subjective welfare of students.

\section{B. Boarding School}

School with boarding school system is integration of Pesantren education system and Madrasah (school). Boarding School is a boarding school system, where learners or students live in dormitories in a school environment. In addition to conducting school activities, students also carry out daily activities in dormitories/cottages. Maksudin argues boarding school is an educational institution where students are not only studying, but they reside and live in the society. Students are faced with conditions far away from home and family with religious sciences taught and some subjects at the same school institution (2010:44)[9].

One of the schools in Yogyakarta that implements the boarding school education model is Pondok Pesantren
Modern Muhammadiyah Boarding School Yogyakarta. The Pondok Pesantren Modern Muhammadiyah Boarding School Yogyakarta which became known as MBS Yogyakarta is a Modern boarding school with boarding schools. MBS Yogyakarta has 3 levels of education Unit, elementary School (SD), Junior High School (SMP) and high School (SMA). SBM Yogyakarta requires junior and senior high school students to stay in a boarding environment. These conditions allow students to get coaching intensively throughout the day.

The Yogyakarta MBS Program includes coaching attitudes, personalities, passion and practice of Islamic values, leadership Social sensitivity, and da'wah ability. Student development at MBS Yogyakarta has various benefits including students with a balance between world science related to intellectual intelligence and emotional intelligence as well as knowledge related to intelligence. Spiritual. MBS students in Yogyakarta received educational intelligence, both intellectual intelligence (IQ), Emotional Intelligence (EQ), Creative Intelligence (CQ) and spiritual Intelligence (SQ) (Susiyani and Subiyantoro, 2017:346)[10]

Boarding school education system can affect the subjective welfare of students especially in the subjective welfare factor as long as the students are attending boarding school. Boarding School is an effective education model to educate the intelligence, skill, character building and the planting of the moral values of learners, so that the students more have a full and distinctive personality. Through boarding school education models, students' spiritual intelligence tends to be well developed.

\section{Spiritual Quotient}

Spiritual quotient or intelligence is the human intelligence that relates to the spiritual value and meaning of life. Spiritual intelligence is sourced from human conscience. According to Zohar and Marshall as the inventor of spiritual intelligence, interpreting the meaning of life is a biological and psychological necessity that must be met in achieving human happiness. Spiritual intelligence helps humans to discover the meaning of life. The meaning of life can lead people in achieving happiness and prosperity.

Spiritual Intelligence guides Mankind to attain the happiness of intrinsic living and guides mankind to peace (Rahmawati, 2016:107).[11]. The Spiritual Intelligence (SQ) is able to enable other human-owned intelligence that is intellectual intelligence (IQ) and Emotional Intelligence (EQ). Spiritual intelligence enables more effective IQ and EQ.

There are still many individuals who have not been able to actualize spiritual intelligence. As a result individuals become far from spiritual value and difficult to interpret life. Only those who are spiritually intelligent are able to give meaning in his life and all people have the same potential to give meaning to his life (Rus'an. 2013:96)[12]. Spiritually Intelligent Youth will be able to give meaning in their hydunya.

Spiritual intelligence can help a teenager to use spiritual resources to solve problems and unhappiness in life so as to attain prosperity. 
So, as teenagers experience problems not necessarily make the youth do negative behaviors but youth are able to control themselves to keep doing good. Even teenagers can still feel prosperous even if they are experiencing problems. Seftiani and Herlena state that spiritual intelligence can be the predictor of subjective prosperity (2018:101-115)[13]

According to Zohar and Marshall, someone whose spiritual intelligence has developed has the ability toonfront and harness suffering and have the ability to confront and exceed pain (2007:14)[14]. Teenagers who have high spiritual intelligence will be better able to face problems and to understand the happiness and unhappiness that arise in his or her life. If youth are able to develop spiritual intelligence well then the youth will avoid harmful deeds in achieving happiness. Karimah (2017) in his research concluded that the higher the spiritual intelligence then the level of adolescent delinquency is getting lower. Youth will be able to achieve subjective wellbeing through the right subjective source of welfare. For one of the benefits of spiritual intelligence to deal with the problems of good and evil, life and death, and the true origins of human suffering and judgment (Zohar and Marshall, 2007:12-13). Spiritual intelligence can be developed during the human life span.

According to Zohar and Marshall (2007:8) Spiritual intelligence must not relate to religion. For some people who have high spiritual intelligence can be gained through formal religion. Spiritual intelligence can be sustained or enhanced through true religious passion and practice, whatsoever religion is embraced, as every religion essentially teaches the truth (Rus'an, 2003:98). However, religion does not guarantee a person has high spiritual intelligence. Nevertheless, a man of spiritual intelligence can be seen from his interactions with the one true God (vertical relations) and how his social ethics is in the environment (horizontal relations).

Based on the explanation above, there are still some high school students of Muhammadiyah Boarding School Yogyakarta who have problems that elicit negative emotions that result in students feeling less prosperous. Therefore, it is important to know how the development of SMA students Muhammadiyah Boarding School Yogyakarta, especially related to happiness and subjective wellbeing. SMA Muhammadiyah Boarding School Yogyakarta is a boarding school that develops aspects of spiritual intelligence. High school student Muhammadiyah Boarding School Yogyakarta belongs to the age of teenagers. High school student Muhammadiyah Boarding School Yogyakarta was chosen because based on findings, the teenagers in high school students of Muhammadiyah Boarding School have issues affecting subjective wellbeing. In addition, SMA Muhammadiyah Boarding School Yogyakarta also develops aspects of spiritual intelligence that is not much developed in other schools.

Based on the problem, researchers have emerged to study more about spiritual intelligence and the subjective welfare level of boarding school students. Despite the lack of research on spiritual intelligence and the subjective welfare level of high school students of Muhammadiyah Boarding School Yogyakarta, it encourages researchers to conduct research "the influence of Spiritual intelligence on Welfare.

\section{A. Types of research \\ III. RESEARCH METHODS \\ This research uses a quantitative approach. The research is classified into causal associative research.}

\section{B. Time and place of research}

This study was conducted for 3 months from January March in 2019. The research venue is located at SMA Muhammadiyah Boarding School Yogyakarta which address at Jalan Prambanan - Piyungan km 2, Marangan, Bokoharjo, Prambanan, Sleman, Yogyakarta.

\section{Target/Subject Research}

The population in this study was high school student Muhammadiyah Boarding School (MBS) Yogyakarta grade $X$ and XI, 2019/2020, which amounted to 642 students, covering X-grade 371 students, class XI amounted to 271 students. The sampling techniques used in this study were Proportionate Stratified Random Sampling. The number of samples is determined by matching the population number with the desired error level in the table developed by ISAAC and Michael. The number of research samples was 227 students, including 131 grade $X$ students and 96 grade XI students.

\section{Data, instruments, and Data collection techniques}

Data collection In this study is intended to obtain data that is relevant, accurate, and reliable. The methods used in this research are questionnaires or polls. The research uses research instruments in the form of subjective welfare scales and spiritual intelligence scales. There are 5 (five) alternative answers i.e. very appropriate (SS), corresponding (S), less appropriate (KS), inappropriate (TS), very inappropriate (STS). Each answer alternative has a score from a range of 0 (zero) to 4 (four). Scoring for data to be quantitative for analysis.

\section{E. Data Analysis Techniques}

The descriptive statistical analysis is used to describe the research variables so it is known for data distribution. In this case the concentration size is by measuring the average (mean), the value that often appears (mode), the middle value (median) and the size of the data spread by measuring the standard deviation (SD). Next created category to know the tendency of each variable.

Category tendency variables like table 1.

Tabel 1. Variable tendency categories Research
Criteria

Note :

$\mathrm{Mi}=$ mean ideal, $\mathrm{SDi}=$ standar deviasi ideal

Category tendency variables like table 1 .

Testing prerequisite analysis was conducted with test normality using Kolmogorov Smirnov test and linierity test using test of linearity on IBM's computer software SPSS Statistics 20. Hypothesis testing using a simple linear regression analysis. 


\section{RESULTS OF RESEARCH AND DISCUSSION}

A. Level of Spiritual Intelligence High School students Muhammadiyah Boarding School Yogyakarta

Known results on the variable of spiritual intelligence is the average (mean) of 96. The value often appears (mode) of 89. Middle Value (median) of 95 and standard deviation (SD) of 11.56, ideal mean (Mi) of 60 and ideal deviation standard (SDi) by 20. Results categorization of tendencies level of spiritual intelligence in table 2 .

Tabel 2. Categorization of tendency levels Spiritual Intelligence

\begin{tabular}{lll}
\hline Category & Frequensy & Relative Frequency \\
\hline High & 211 & $92,95 \%$ \\
Middle & 16 & $7,05 \%$ \\
Low & 0 & 0 \\
\hline
\end{tabular}

The level of spiritual intelligence of high School students of Muhammadiyah Boarding School Yogyakarta means that students have religious spiritual relationships, social relations and good behavior. A good spiritual relationship is characterized by carrying out spiritual activities to the Almighty God in the form of praying, grateful, worship, studying religious sciences, believing in religion and believing in the wisdom.

Students who have high spiritual intelligence have good and minimal ethics doing bad deeds. This is in accordance with the opinions here and Noya (2012:174) that a person who has high spiritual intelligence has a good moral sense and is able to distinguish between bad deeds and the good. A person who has high intelligence is acting on his or her social neighbor according to the moral value he possesses. Husni Tanra describes that a person with high spiritual intelligence realizes when he or she is detrimental to others means that he is detrimental to himself (Rus'an, 2013:98). It delivers individuals to both ethically and achieve high spiritual intelligence. In addition, students who have high spiritual intelligence also have high empathy. A. Husna Tanra (in Rus'an 2013:99) also stated the same thing that high empathy individuals can deliver at a high level of spiritual intelligence.

Students who have a meaningful spiritual intelligence that they also exercise spiritual activity to the Almighty God, are ethically good but each do some less good behaviour such as committing a rule of offense and lying To cover his mistakes. Students with a moderate level of spiritual intelligence also have empathy but not as often as students with high spiritual intelligence.

B. The subjective welfare level of high school students Muhammadiyah Boarding School Yogyakarta

Known results in the subjective welfare variable mean an average of 104 . The frequent value (mode) is 105 , the middle value (median) of 104 and the deviation Standard (SD) of 14.45 , the ideal mean (Mi) of 70 and the ideal deviation standard (SDi) of 23.3. Results categorization tendency to subjective welfare levels in table 3 .

Tabel 3. Categorization of tendency levels Subjective prosperity

\begin{tabular}{lll}
\hline Category & Frequensy & Relative Frequency \\
\hline High & 176 & $77,53 \%$ \\
Middle & 51 & $22,47 \%$ \\
Low & 0 & 0 \\
\hline
\end{tabular}

The subjective welfare level of high school student Muhammadiyah Boarding School Yogyakarta means that the dominant students feel the positive pronunciation, have low negative aphek and feel the satisfaction of what is owned or hope in his life. Satisfaction that encourages the high degree of subjective welfare of high school student Muhammadiyah Boarding School Yogyakarta is one of satisfaction with family.

This is in accordance with the Goddess's declaration (2004:33) stating that students who live in the trend can still fulfill their needs in the care of parents or families so that students can feel happiness even though it is far from right to live. Through fulfillment of the needs of the family, students can feel the satisfaction of the family, encouraging the height of subjective welfare of students.

Students who have high subjective welfare have a high sense of gratitude. It is in accordance with Sativa and Helmi who stated that having a high level of gratitude, will have a high level of happiness as there is a tendency to be more satisfied and optimistic when compared to individuals who do not Grateful (2013)[15]. Students ' perceived happiness for being grateful will encourage students to perceive his or her life positively so that students feel subjective prosperity. mo McCullough and Polak stating that gratitude gives a positive aphek, reduces negative aphek, enhances life satisfaction that will affect subjective wellbeing. (2006)[16]

The high subjective prosperity has the meaning that affective students feel happy and the cognitive students assess his life satisfactorily. A person is said to have a high subjective welfare when fulfilling the criteria is to have a feeling of happiness, satisfied with his life and have a low level of Neurotism (Nayana, 2013:233).

Students who have subjective prosperity who are in a meaningful manner have negative emotions that are sufficiently low, feel positive emotions quite high and feel sufficient satisfaction in his or her life. The student's life satisfaction includes self-satisfaction, family, peers, health, finances, employment and leisure.

C. Influence of Spiritual intelligence on the subjective welfare of high school students Muhammadiyah Boarding School Yogyakarta

The hypothesis of this research is "spiritual intelligence affects the subjective welfare of high school student Muhammadiyah Boarding School Yogyakarta". Through a simple linear regression analysis known to the outcome of the significance value (Sig.) of 0.000 is smaller than the probability 0.05 so that it can be concluded that the hypothesis is acceptable, meaning that "spiritual intelligence affects The subjective welfare of high school students Muhammadiyah Boarding School Yogyakarta ".

The result of a regression equation is $\mathrm{Y}=21.104+0$, 866X which means that spiritual intelligence affects positively to subjective wellbeing. This positive influence means the increasing spiritual intelligence will influence the bjective improvement of wellbeing. The value of $\mathrm{R}$ intelligence $(\mathrm{X})$ affects the subjective prosperity $(\mathrm{Y})$ by $48 \%$. 
The results of this study were strengthened by the research conducted by Nur Ayu Seftiani and Benny Herlena (2018) titled "Spiritual Intelligence as a subjective welfare predictor of students". The study resulted in a conclusion that spiritual intelligence can predict subjective wellbeing. It is increasingly strengthening that spiritual intelligence affects the subjective welfare although in this research the subject is a school student.

The results of this research also proved the research results of Tri Na'imah and Tukiran Tanireja (2017)[17] entitled "Student Well-being in Javanese youth" that the spiritual dimension found as a source of subjective prosperity is true. This study shows that the spiritual dimension of spiritual intelligence affects the sujective welfare of a student. Dewi stating that if someone is able to comment on the spritual intellect in his life, then happiness will be gained. (2017:147)[18]. Spiritual intelligence means optimizing the potential of good in students. Students will do good deeds and avoid bad deeds. By doing good deeds, students will feel peace, tranquility, happiness and other positive aphek that will deliver students to subjective prosperity.

Spiritual intelligence can influence the subjective welfare of the students one of them because of the spiritual activities that students do. Spiritual intelligence means that students are able to interact with God through spiritual and religious activities. Through spiritual activity and the plainness of students will feel peace and happiness. This is in accordance with the opinion of Abdul Wahid Hasan (in Nisa, 2009:83)[19] That one can feel the high happiness of one of them by feeling the presence of God that is so close in remembrance, praying, prayer, and other activities. The tranquility and happiness that students feel will lead to the subjective welfare of the students.

Spiritual intelligence can affect subjective well-being because spiritual interactions - religious, social - religious, and good/bad behaviors that are aspects of spiritual intelligence are shown to affect subjective wellbeing. Spiritual intelligence can help a student to use spiritual resources to resolve the problem in his or her hydunya. So that students are spared from negative Aphek, have positive aphek and satisfaction in areas of life. Therefore spiritual intelligence affects the subjective welfare of a teenager/student.

Pramudita and Prastiti (2015)[20] explained that other factors that contributed to the subjective welfare of the students were self-efficacy students. Self-Efficacy is an individual belief in its ability to successfully perform tasks to achieve certain outcomes. Students who feel confident in their ability to accomplish the task properly will be more easily satisfied and feel happy or happy to encourage subjective wellbeing. Khairat and Adiyanti (2015)[21]; Sativa and Helmi (2013); Fajriani \& Suconcerned (2017)[22] also describes other factors that contribute to the subjective welfare of self-esteem (self esteem). Self-esteem refers to an individual's judgment of his or her worthiness and shows the extent to which individuals are able to confidently.

Self-Esteem is an individual's attitude toward itself, whether the individual accepts or rejects himself, which is based on an individual's judgment of himself. Self-esteem makes students feel valuable so satisfied with him. The sense of satisfaction that students have encourages subjective wellbeing.
Another factor that affects the subjective prosperity in addition to the spiritual intelligence expressed by Diponegoro (2006)[23] is the management of stress. When the way to avoid stress is correct, it will improve the subjective welfare of individuals. Individuals who are spared from stress allow to avoid negative emotions. In addition to other factors that enhance the subjective welfare are learning achievements (Hamdana and Alhamdu, 2015)[24] and social support (Samputri and Sakti, 2015)[25].

The evidence of hypotheses in this study can provide information that students ' spiritual intelligence needs to be improved so that students ' subjective welfare can increase because the higher the spiritual intelligence of students then the higher The subjective welfare of students. Conversely, the lower the level of spiritual intelligence of students then the lower the subjective welfare of students.

\section{CONCLUTION}

Based on the results of research and discussion can be concluded there is a influence of spiritual intelligence on the subjective welfare of high school students Muhammadiyah Boarding School Yogyakarta. This is evidenced by the high level of spiritual intelligence followed by the high level of subjective welfare of students. Advice to Students, it is hoped that students are motivated to improve the quality of life by increasing the factors that support the spiritual intelligence and subjective welfare of the students especially to undergo and complete education targets optimally. Advuce to school, expected by knowing the factors that support the high spiritual intelligence and the subjective welfare of the students, the school is able to assist the students in fulfilling these factors through the school/boarding program. Schools are also more concerned about the issue of students who may be, moderate, or have been happening by conducting guidance and counseling services. Especially the problems that affect spiritual intelligence and the subjective welfare of students. Advice to further researchers, it is hoped that researchers can further explore the information about spiritual intelligence and more subjective wellbeing over again using other instruments/additions in addition to questionnaires. It can also be to do research on other factors that affect subjective wellbeing.

\section{REFERENCES}

1. Grimaldy, D. V., Nirbayaningtyas, R. B., \& Haryanto, H. C. (2017). Efektivitas jurnal kebahagiaan dalam meningkatkan self esteem pada anak jalanan. Jurnal Ilmiah Psikologi, Vol 8, No 2, 100-110.

2. Anggoro, W. J. \& Widhiarso, W. (2010). Konstruksi dan identifikasi property psikometris instrumen pengukuran kebahagiaan berbasis pendekatan indigenous psychology: studi multitrait-multimethod. Jurnal Psikologi, Vol 37, No 2, 176-188.

3. Diener, E., Lucas, R. E., \& Oishi, S. (2005). Subjective wellbeing: the science of happiness and life satisfaction. New York, NY: Oxford University Press.

4. Diener, E. (2000). Subjective well-being the science of happiness and a proposal for a national index. American Psycologist, Vol 55, No 1, 3443.

5. Maslilah, S. (2017). Faktor yang mempengaruhi kesejahteraan subjektif anak didik lembaga pembinaan khusus anak. Jurnal Psikologi Insight, Vol 1, No 1, 82-94. 
6. Izzaty, R. E., Suardiman, S. P., Ayriza, Y., et al. (2013). Perkembangan peserta didik. Yogyakarta: UNY Press.

7. Azizah. (2013). Kebahagiaan dan permasalahan di usia remaja (penggunaan informasi dalam pelayanan bimbingan individual). Jurnal Bimbingan dan Konseling Islam, Vol 4, No 2, 295-316.

8. Nayana, F. N. (2013) Kefungsian keluarga dan subjective well-being pada remaja. Jurnal Psikologi Terapan, Vol 1, No 2, 230-244.

9. Maksudin. (2010). Pendidikan islam alternatif mambangun karakter melalui sistem boarding school. Yogyakarta: UNY Press.

10. Susiyani, A. S \& Subiyantoro. (2017). Manajemen boarding school dan relevansinya dengan tujuan pendidikan islam di muhammadiyah boarding school (mbs) yogyakarta. Jurnal Pendidikan Madrasah, Vol 2, No 2. 327-347.

11. Rahmawati, U. (2016). Pengembangan kecerdasan spiritual santri: studi terhadap kegiatan keagamaan di rumah tahfizqu deresan putri yogyakarta. Jurnal Penelitian, Vol 10, No 1, 97-124.

12. Rus'an. (2013). Spiritual quotient (sq): the ultimate intelligence. Lentera Pendidikan, Vol 16, No 1, 91-100.

13. Seftiani, N. A. \& Herlena, B. (2018). Kecerdasan spiritual sebagai prediktor kesejahteraan subjektif pada mahasiswa. Jurnal Psikologi Integratif, Vol 6, No 1, 101-105.

14. Zohar, D \& Marshall, I. (2007). Sq: kecerdasan spiritual. (Terjemahan Rahmani Astuti \& Ahmad Nadjib Burhani). Bandung: PT Mizan Pustaka. (Edisi asli diterbitkan tahun 2000 oleh Bloomsbury, Great Britain).

15. Sativa, A. S. \& Helmi, A. F. (2013). Syukur dan harga diri dengan kebahagiaan remaja. Psikologi, Vol 5, No 2.

16. Polak, E. L. \& Mccullough, M. E. (2007). Is gratitude an alternative to materialism?. Journal of Happiness Studies, 7, 346-360.

17. Na'imah, T. \& Tanireja, T. (2017). Student well-being pada remaja jawa. Jurnal Penelitian Psikologi, Vol 2, No 1, 1-11.

18. Dewi, E. (2017). Konstruksi kebahagiaan dalam bingkai kecerdasan spiritual. Substantia, Vol 19, No 2, 133-148.

19. Nisa, K. (2009). Hidden curriculum: upaya peningkatan kecerdasan spiritual siswa. Lentera Pendidikan, Vol 12, No 1, 72-86.

20. Pramudita, R. \& Pratisti, W. D. (2015). Hubungan antara self-efficacy dengan subjective well-being pada siswa SMA negeri 1 belitang. Disajikan dalam Seminar psikologi dan kemanusiaan, Universitas Muhammadiyah Surakarta.

21. Khairat, M. \& Adiyanti, M. G. (2015). Self-esteem dan prestasi akademik sebagai prediktor subjective well-being remaja awal. Gadjah Mada Journal of Psychology, Vol 1, No 3, 180-191.

22. Fajriani, I. T. \& Suprihatin. T. (2017). Harga diri, kepuasan kerja dan kesejahteraan subjektif pada guru madrasah tsanawiyah. Jurnal Proyeksi, Vol 12, No 1, 67-76.

23. Diponegoro, A. M. (2006). Peran stress management terhadap kesejahteraan subjektif. Jurnal Humanitas, Vol 3, No 2, 137-145.

24. Hamdana, F. \& Alhamdu. (2015). Subjective well-being siswa MAN 3 palembang. Jurnal Psikologi Islam, Vol 1 No 1, 95-104.

25. Samputri, S. K. \& Sakti, H. (2015). Dukungan sosial dan subjective well being pada tenang kerja wanita PT arni family ungaran. Jurnal Empati, Vol 4(4), 208-216.

\section{AUTHOR PROFILE}

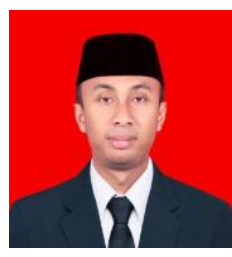

Agus Yuliyanto. The Author is currently studying in Postgraduate Social Studies Education at Yogyakarta State University (Universitas Negeri Yogyakarta), Yogyakarta, Indonesia. The author is interested in research related to the influence of spiritual quotient toward subjective well-being of student of Muhammadiyah Boarding School Yogyakarta High School issues. agusyuliyanto.2017@student.uny.ac.id

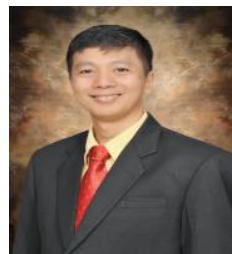

Setyabudi Indartono, Ph.D. Scopus Author ID 37123968000, Assoc. Prof. in Human Resources Management, Dept. Head of Management School, Yogyakarta State University, (Universitas Neger Yogyakarta) Yogyakarta, Indonesia. setyabudi_indartono@uny.ac.id 